\title{
The strategy for implementing National Fish Logistics System (NFLS) in Bitung Fishing Port, Bitung, Indonesia
}

\author{
Strategi implementasi Sistim Logistik Ikan Nasional (SLIN) di Pelabuhan \\ Perikanan Samudera Bitung, Bitung, Indonesia \\ Maltonius Tassi ${ }^{1 *}$, Rene Charles Kepel ${ }^{2}$, and Hengky Sinjal ${ }^{2}$ \\ ${ }^{1}$ Program Studi Ilmu Perairan, Program Pascasarjana Universitas Sam Ratulangi. Jln. Kampus Unsrat Kleak, \\ Manado 95115, Sulawesi Utara, Indonesia. \\ ${ }^{2}$ Fakultas Perikanan dan Ilmu Kelautan, Universitas Sam Ratulangi, Manado, Sulawesi Utara, Indonesia. \\ *E-mail:maltoniustassi@gmail.com
}

\begin{abstract}
Regulation of the Minister of Marine and Fisheries of Indonesia 2014 (No.5/MEN/2014) regarding National Fish Logistics System (NFLS) is a policy issued in order to overcome the problem of limited raw materials of fish. In order to implement the regulation optimally at Bitung Fishing Port (BFP), this study was carried out which aimed to predict production of capture fisheries landed in BOFP for the next 10 years, to identify external and internal factors in formulating alternative strategies, and to set up priorities strategy for NFLS implementation at the BOFP. This descriptive study was carried out using several analyses, namely Simple Regression Analysis, SWOT (Strengths, Weakness, Opportunities, and Threats), and Quantitative Strategic Planning Matrix (QSPM). The result of the study showed that the increase in production can still occur in accordance with the projections of the secondary data over the past 10 years. The internal factors that become a strength in the implementation of NFLS was the vision of BOFP to increase landings of fishery catch (score 0.660 ). The weakness was existence of the storehouse of fish which still limited (score 0.440). The external factors seen as opportunities of NLSF implementation was the location of potential fishing ground (score 0,495 ), while the threats was the cost of fishing operations which are relatively expensive (score 0.440 ). This study also formulated six alternative strategies that can be applied in the implementation of NLSF at BOFP and the best strategies are the optimization of the fleet, loading and unloading facilities, and logistics channeling facilities in fishing ground with the potential to increase fisheries production (TAS $=5,544)$.
\end{abstract}

Keywords: national logistic system of fish; fishery management; Bitung; Indonesia.

Abstrak: Peraturan Menteri Kelautan dan Perikanan 2014 (No.5/MEN/2014) tentang sistem logistik ikan nasional (SLIN) merupakan kebijakan dalam upaya mengatasi masalah keterbatasan bahan baku ikan. Untuk mengimplementasikan peraturan tersebut secara optimal di Pelabuhan Perikanan Samudera Bitung (PPSB), maka penelitian ini dilakukan di mana bertujuan untuk memprediksi produksi perikanan tangkap yang didaratkan di PPSB untuk 10 tahun yang akan datang, mengidentifikasi faktor eksternal dan internal dalam merumuskan strategi alternatif, dan menetapkan prioritas strategi implementasi SLIN. Penelitian ini merupakan penelitian deskriptif menggunakan beberapa analisis, yaitu analisis Regresi Sederhana, SWOT (Strengths, Weakness, Opportunity, Thread), dan Quantitative Strategic Planning Matriks (QSPM). Hasil penelitian menunjukan, bahwa peningkatan produksi masih dapat terjadi sesuai dengan proyeksi data sekunder selama 10 tahun terakhir. Faktor internal yang menjadi kekuatan dalam implementasi SLIN ialah adanya visi PPSB untuk meningkatkan pendaratan hasil perikanan tangkap (skor 0,660). Sedangkan kelemahannya ialah keberadaan gudang penyimpanan ikan yang masih terbatas (skor 0,440 ). Faktor eksternal yang menjadi peluang dalam implementasi SLIN ialah lokasi daerah penangkapan ikan yang potensial (skor 0,495 ). Sedangkan ancamannya ialah biaya operasi penangkapan ikan yang relatif mahal (skor 0,440). Penelitian ini juga merumuskan enam alternatif strategi yang dapat diterapkan dalam implementasi SLIN di PPSB di mana strategi terbaiknya ialah optimasi armada, sarana bongkar muat, dan sarana penyalur logistik pada daerah penangkapan ikan yang potensial untuk meningkatkan produksi perikanan tangkap (TAS $=5,544$ ).

Kata-kata kunci: sistem logistik ikan nasional; pengelolaan perikanan; Bitung; Indonesia.

\section{PENDAHULUAN}

Indonesia adalah salah satu negara kepulauan terbesar di dunia, yang mempunyai garis pantai terpanjang kedua setelah Kanada, dengan panjang sekitar $81.000 \mathrm{~km}$ dan luas wilayah laut 5,8 juta 
$\mathrm{km}^{2}$, termasuk Zona Ekonomi Ekslusif Indonesia (ZEEI), yang memberikan kontribusi terhadap hasil tangkapan pada tahun 2011 sebesar 5,4 juta ton/tahun (BAPPENAS, 2012). Sebagai negara kepulauan, hal ini berimplikasi pada pola penyediaan stok ikan untuk kebutuhan industri dan konsumsi masyarakat. Hal ini terjadi di Kota Bitung di mana realisasi produksi rata-rata per hari selama tahun 2014 hanya mencapai 716 ton atau baru terpenuhi setengahnya, sementara kebutuhan bahan baku Unit Pengolahan Ikan (UPI) di Kota Bitung (berjumlah 53 unit, yang terdiri dari 7 unit pengalengan, 5 unit ikan kayu, 12 unit proses tuna segar dan 29 unit proses ikan beku) ialah 1.400 ton per hari (Asosiasi Unit Pengolahan Ikan Kota Bitung, 2014).

Terkait dengan permasalahan krisis bahan baku ikan yang sering menerpa sektor perikanan selama ini, maka pada tahun 2014, Kementerian Kelautan dan Perikanan (KKP) mengeluarkan suatu kebijakan sebagai jaminan ketersediaan, keterjangkauan, dan keberlanjutan pemenuhan konsumsi ikan dan industri pengolahan ikan. Jaminan tersebut dituangkan dalam Peraturan Menteri Kelautan dan Perikanan (Permen KP) Nomor PER 5/MEN/2014, tentang Sistem Logistik Ikan Nasional (SLIN). Operasional pengelolaan SLIN untuk pusat produksi dan/atau pusat pengumpulan, dan pusat distribusi berada di lokasi yang menjadi pelabuhan pangkalan atau pelabuhan perikanan serta pusat distribusi ditetapkan berada di lokasi yang memiliki industri pengolahan ikan yang telah berkembang.

Pelabuhan Perikanan Samudera Bitung (PPSB) adalah pelabuhan perikanan Tipe A di Kota Bitung-Sulawesi Utara, yang merupakan pusat pendaratan hasil tangkapan ikan nelayan Kota Bitung, yang memiliki industri perikanan yang berkembang. Sebagai pusat pendaratan ikan yang memiliki industri pengolahan, maka implementasi SLIN di PPSB harus dilakukan dalam upaya mengurangi masalah kekurangan bahan baku industri dan harga yang tidak stabil di Kota Bitung.

Dalam implementasi SLIN, persoalan pokok yang dialami saat ini ialah bagaimana ketersediaan jenis dan volume produksi yang didaratkan di PPSB untuk dapat memproyeksikan produksi dalam masa yang datang. Persoalan lainnya yang ada ialah apa yang menjadi faktor penentu dalam implementasi SLIN dan strategi yang akan digunakan. Erdasarkan latar belakang tersebut di atas, maka dilakukan penelitian strategi implementasi sistem logistik ikan nasional di PPSB.

\section{MATERIAL DAN METODA}

Penelitian ini dilakukan di PPS Bitung, Provinsi Sulawesi Utara, pada bulan Mei-Agustus 2015, yang meliputi pengambilan data primer melalui teknik wawancara secara mendalam, distribusi kuisioner dan observasi lapangan, serta data sekunder melalui kajian pustaka. Metode penelitian yang digunakan ialah penelitian survei.

Jenis data yang dikumpulkan dalam penelitian ini adalah data kualitatif dan kuantitatif. Pemilihan responden dilakukan secara sengaja sesuai dengan tujuan penelitian, yaitu mengidentifikasi dan menganalisis kondisi faktorfaktor internal dan eksternal, dan rumusan strategi yang digunakan.

Analisis data menggunakan analisis Regresi Linear Sederhana dengan dengan persamaan umum, yaitu: $\mathrm{Y}=\mathrm{a}+\mathrm{bX}$ (Melynda, 2012); sedangkan untuk mendapatkan strategi digunakan analisis SWOT (Strengths, Weakness, Opportunities, and Threats) melalui evaluasi lingkungan internal dan eksternal, kemudian membuat model matriks kesimpulan analisis faktor internal dan eksternal. Selanjutnya, matriks analisis SWOT dibuat untuk mendapatkan alternatif strategi, dan dilanjutkan dengan analisis QSPM (Quantitative Strategic Planning Matrix) untuk menetapkan prioritas strategi implementasi SLIN di PPSB.

\section{HASIL DAN PEMBAHASAN}

Aktivitas kapal perikanan yang masuk di PPSB dari tahun 2005 sampai dengan 2014 mengalami penurunan rata-rata $0,83 \%$ atau 350 kali kunjungan kapal per tahun. Hal ini menunjukkan, bahwa kegiatan penangkapan ikan belum terlaksana secara optimal karena terjadi penurunan kunjungan kapal setiap tahun. Sementara itu, produksi ikan yang didaratkan di PPSB dalam 10 (sepuluh) tahun terakhir (2005-2014) mengalami peningkatan ratarata $44,62 \%$ per tahun atau $11.697,079$ ton per tahun. Berdasarkan analisis aritmatik, diprediksi pendaratan ikan 10 tahun ke depan dari tahun 20152024 mengalami peningkatan.

Hasil nilai pembobotan yang menjadi faktor kekuatan utama bagi implementasi SLIN ialah Visi PPSB untuk peningkatan pendaratan hasil perikanan tangkap dan ketersediaan armada penangkapan ikan, ditunjukkan dengan nilai bobot masingmasing 0,165 dan 0,163 . Nilai rating yang diperoleh kedua faktor tersebut sebesar 4, artinya sangat kuat dengan skor 0,660 dan 0,650. Hal ini mengindikasikan, bahwa kedua faktor tersebut 
sangat penting dan sangat kuat pengaruhnya dalam mengimplementasikan SLIN.

Adapun faktor internal kelemahan yang harus mendapat perhatian ialah gudang penyimpanan ikan yang masih terbatas, gudang penyimpanan bahan dan alat tangkap, dan toko bahan dan alat tangkap ikan yang belum ada; masing-masing ditunjukkan dengan nilai bobot sebesar 0,147, 0,142, dan 0,115. Ketiga faktor tersebut memperoleh nilai rating 3, artinya agak kuat dengan skor sebesar 0,440, 0,425, dan 0,344 . Hal ini dapat diartikan, bahwa ketiga faktor tersebut sangat penting dan merupakan bagian yang agak kuat kelemahannya dalam upaya mengimplementasikan SLIN di PPSB. Namun demikian, total skor faktor internal hasil perhitungan matriks IFAS ialah sebesar 2,868 mengindikasikan, bahwa faktor strategi internal termasuk kategori "kuat" (David, 2000). Hal ini menunjukkan, bahwa posisi internal PPSB dalam mengimplementasikan SLIN mampu memanfaatkan faktor-faktor kekuatan yang ada untuk mengatasi faktor-faktor kelemahan.

Hasil pembobotan faktor peluang menunjukkan, bahwa peluang utama yang dimiliki PPSB untuk implementasi SLIN ialah lokasi daerah penangkapan ikan yang potensial dan adanya kebijakan pemerintah yang mendukung sistem logistik ikan; bobot masing-masing sebesar 0,165 dan 0,163 . Nilai rating yang diperoleh kedua faktor tersebut ialah 3, yang artinya kemampuan merespon baik. Hal ini berarti, bahwa faktor peluang tersebut sangat penting, dan PPSB mampu merespon peluang itu dengan baik.

Adapun faktor eksternal untuk ancaman yang harus diantisipasi yaitu biaya operasi penangkapan ikan yang relatif mahal dan terjadinya IUU fishing dengan nilai bobot sebesar 0,147 dan 0,142 . Kedua faktor tersebut memperoleh nilai rating 3 , artinya agak kuat dengan skor sebesar 0,440 dan 0,425. Hal ini berarti, bahwa kedua faktor tersebut sangat penting dan mengancam dengan tingkat agak kuat dalam upaya mengimplementasikan SLIN di PPSB.

Faktor ancaman berikutnya yaitu jaringan logistik ikan antar pelabuhan perikanan belum mendukung (bobot 0,115 ; rating 2), artinya agak lemah dan skor sebesar 0,229. Hal ini berarti, bahwa faktor jaringan logistik ikan antar pelabuhan perikanan belum mendukung. Faktor ini sangat penting dan mengancam, namun dengan tingkat agak lemah dalam mengimplementasikan SLIN di PPSB. Total skor faktor strategi eksternal berdasarkan perhitungan matriks EFAS adalah sebesar 2,518. Hal ini berarti, bahwa faktor strategi eksternal termasuk kategori "kuat". Hal ini menunjukkan, bahwa posisi eksternal PPS Bitung dalam mengimplementasikan SLIN dapat memanfaatkan peluang dan mengatasi ancaman yang ada. Berdasarkan perhitungan matriks IFAS dan EFAS, berbagai alternatif strategi dapat dirumuskan (Tabel 1).

Setelah mendapat alaternatif strategi menggunakan analisis SWOT, maka dilanjutkan dengan analisis QSPM di mana nilai TAS (total attractives score) dari implementasi SLIN di PPSB menunjukkan nilai tertinggi yaitu strategi alternatif optimalisasi armada, sarana bongkar muat, dan sarana penyalur logistik guna memanfaatkan daerah penangkapan ikan yang potensial untuk meningkatkan produksi perikanan tangkap, dengan skor sebesar 5,544. Hal ini berarti, bahwa strategi implementasi SLIN di PPSB melalui optimalisasi armada, sarana bongkar muat, dan sarana penyalur logistik guna memanfaatkan daerah penangkapan ikan yang potensial untuk meningkatkan produksi perikanan tangkap menjadi pilihan utama.

Strategi alternatif pembangunan gudang penyimpanan ikan, gudang dan toko bahan, dan alat tangkap dalam rangka merenspon tingginnya permintaan ikan menjadi pilihan kedua dengan skor sebesar 5,07. Strategi peningkatan kualitas produk perikanan untuk dapat berdaya saing di pasar bebas menjadi pilihan ketiga dengan skor sebesar 4,939.

Strategi peningkatan kualitas SDM nelayan untuk melakukan kegiatan penangkapan ikan dalam meresponi permintaan pasar dan dukungan sarana pelabuhan laut yang berskala internasional menjadi pilihan keempat dengan skor sebesar 4,803. Strategi optimalisasi pusat informasi pelabuhan perikanan mendapatkan informasi menjadi pilihan kelima dengan skor 4,426. Adapun strategi penambahan jumlah SDM aparatur pelabuhan untuk pengendalian IUU fishing di pelabuhan perikanan menjadi pilihan keenam dengan skor sebesar 4,377.

\section{KESIMPULAN}

Melalui penelitian ini, dapat disimpulkan beberapa hal sebagai berikut:

1. Volume pendaratan hasil tangkapan ikan untuk 10 tahun ke depan diprediksi akan mengalami peningkatan.

2. Faktor-faktor lingkungan internal dan eksternal menunjang implementasi SLIN di PPSB dengan urutan skor yang tertinggi yaitu:

a. Faktor lingkungan internal dengan kekuatan yang berpengaruh yaitu (i) visi PPSB untuk peningkatan pendaratan hasil perikanan tangkap dengan; (ii) ketersediaan armada penangkapan ikan; (iii) ketersediaan sarana 
Tassi et al.: The strategy for implementing National Fish Logistics System (NFLS)...

Tabel 1. Penyusunan Faktor Stretgis Implementasi SLIN di PPS Bitung tahun 2015

\begin{tabular}{|c|c|c|}
\hline IFAS & $\begin{array}{l}\text { KEKUATAN/ STRENGT } \\
\text { - Visi PPS Bitung untuk peningkatan } \\
\text { Pendaratan hasil perikanan tangkap } \\
\text { - Ketersediaan armada Penangkapan ikan } \\
\text { - Ketersediaan sarana bongkar muat } \\
\text { kapal } \\
\text { - Ketersediaan sarana penyalur logistik } \\
\text { operasional kapal perikanan (SPDN, } \\
\text { Pabrik Es, dan Kios Perbekalan) } \\
\text { - Ketersediaan pusat informasi pelabuhan } \\
\text { perikanan }\end{array}$ & $\begin{array}{l}\text { KELEMAHAN /WEAKNESS } \\
\text { - Gudang penyimpanan ikan yang } \\
\text { masih terbatas } \\
\text { - Belum ada gudang penyimpanan } \\
\text { bahan dan alat tangkap ikan } \\
\text { - Belum ada toko bahan dan alat } \\
\text { tangkap ikan } \\
\text { - Kuantitas SDM Aparatur pelabuhan } \\
\text { - Tingkat pendidikan nelayan yang } \\
\text { masih rendah }\end{array}$ \\
\hline \multicolumn{3}{|l|}{ EFAS } \\
\hline 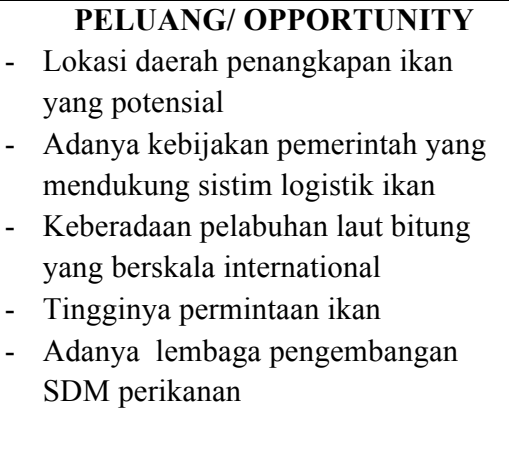 & \begin{tabular}{l}
\multicolumn{1}{c}{ STRATEGI - SO } \\
- Optimalisasi armada, sarana bongkar \\
muat, dan sarana penyalur logistik \\
guna memanfaatkan daerah \\
penangkapan ikan yang potensial \\
untuk meningkatkan produksi \\
perikanan tangkap \\
- Optimalisasi pusat informasi pelabuhan \\
perikanan mendapatkan informasi
\end{tabular} & $\begin{array}{l}\text { STRATEGI - WO } \\
\text { - Pembangunan gudang penyimpanan } \\
\text { ikan, gudang dan toko bahan, alat } \\
\text { tangkap dalam rangka merenspon } \\
\text { tingginnya permintaan ikan } \\
\text { - } \text { Peningkatan kualitas SDM Nelayan } \\
\text { untuk melakukan kegiatan } \\
\text { penangkapan ikan dalam meresponi } \\
\text { permintaan pasar serta dukungan } \\
\text { sarana pelabuhan laut yang berskala } \\
\text { internasional }\end{array}$ \\
\hline $\begin{array}{l}\text { ANCAMAN/ TREATH } \\
\text { - Jaringan logistik ikan antar } \\
\text { pelabuhan perikanan belum } \\
\text { mendukung } \\
\text { - Terjadinya IUU fishing } \\
\text { - Biaya operasi penangkapan ikan } \\
\text { yang relatif mahal } \\
\text { - Pelaksanaan kebijakan yang } \\
\text { tumpang tindih terhadap kapal } \\
\text { perikanan } \\
\text { - Aglomerasi Perekonomian Global } \\
\text { dan Regional }\end{array}$ & $\begin{array}{l}\text { STRATEGI - ST } \\
\text { - Peningkatan kualitas produk perikanan } \\
\text { untuk dapat berdaya dipasar bebas }\end{array}$ & \begin{tabular}{l}
\multicolumn{1}{c}{ STRATEGI - WT } \\
- \\
Penambahan jumlah SDM aparatur \\
pelabuhan untuk pengendalian IUU \\
fishing di pelabuhan perikanan
\end{tabular} \\
\hline
\end{tabular}

penyalur logistik operasional kapal perikanan (SPDN, pabrik es, dan kios perbekalan); (iv) ketersediaan sarana bongkar muat kapal perikanan; dan (v) ketersediaan pusat informasi pelabuhan perikanan dengan.

b. Faktor lingkungan eksternal dengan peluang yang berpengaruh yaitu (i) lokasi daerah penangkapan ikan yang potensial; (ii) adanya kebijakan pemerintah yang mendukung sistem logistik ikan; (iii) tingginya permintaan ikan; (iv) keberadaan pelabuhan laut bitung yang berskala internasional; dan (v) adanya lembaga pengembangan SDM perikanan.

3. Strategi implementasi SLIN di PPSB menghasilkan alternatif strategi dengan urutan prioritas sebagai berikut: (i) optimalisasi armada, sarana bongkar muat, dan sarana penyalur logistik pada daerah penangkapan ikan yang potensial untuk meningkatkan produksi perikanan tangkap; (ii) pembangunan gudang penyimpanan ikan, gudang dan toko bahan, dan alat tangkap dalam rangka merenspon tingginnya permintaan ikan; (iii) peningkatan kualitas produk perikanan untuk dapat berdaya saing di pasar bebas; (iv) peningkatan kualitas 
SDM nelayan untuk melakukan kegiatan penangkapan ikan dalam meresponi permintaan pasar dan dukungan sarana pelabuhan laut yang berskala internasional; (v) optimalisasi pusat informasi pelabuhan perikanan mendapatkan informasi; dan (vi) penambahan jumlah SDM aparatur pelabuhan untuk pengendalian IUU fishing di pelabuhan perikanan.

4. Prioritas strategi yang dipilih dan menjadi pilihan utama dalam implementasi SLIN di PPSB yaitu optimalisasi armada, sarana bongkar muat, dan sarana penyalur logistik pada daerah penangkapan ikan yang potensial untuk meningkatkan produksi perikanan tangkap.

\section{REFERENSI}

BAPPENAS (2012). Direktorat Kelautan dan Perikanan. 2010. Data dan Informasi Kelautan dan Perikanan.

DAVID, F. R. (2000). Manajemen Strategis Edisi 10. Jakarta: Penerbit Salemba Empat.

PRASETIYO, A. (2008). Perencanaan Struktur Jembatan Rangka Baja Kali Cibereum Kabupaten Cilacap Jawa Tengah. Skripsi. Program Studi Teknik Sipil Fakultas Teknik Universitas Katolik Soegijapranata.

ASOSIASI UNIT PENGOLAHAN IKAN BITUNG (2014). Data Unit Pengolahan Ikan Kota Bitung Tahun 2014.

Diterima: 5 Juni 2015

Disetujui: 28 Oktober 2015 